\title{
INTERCULTURAL RELATIONS IN GEORGIA AND TAJIKISTAN: A POST-CONFLICT MODEL
}

\author{
J.W. BERRY ${ }^{\mathrm{a}, \mathrm{b}}$, V.N. GALYAPINA ${ }^{\mathrm{b}}$, N.M. LEBEDEVA ${ }^{\mathrm{b}}$, \\ Z.KH. LEPSHOKOVA ${ }^{\text {b }}$, T.A. RYABICHENKO ${ }^{\text {b1 }}$
}

\author{
${ }^{a}$ Queen's University, 154 Albert Str., Kingston, ON Canada, K7L 3N6 \\ ${ }^{b}$ National Research University Higher School of Economics, 20 Myasnitskaya Str., Moscow, 101000, \\ Russian Federation
}

\begin{abstract}
The paper presents the results of two studies of intercultural relations in post-Soviet Georgia and Tajikistan. These countries have in common a sharp decline in cultural diversity as a result of wars and conflicts, and this model of intercultural relations on post-Soviet space was identified as a post-conflict model. The goal of this study was to evaluate three hypotheses of intercultural relations: multiculturalism, contact and integration (Berry, 2017) among majority members and the ethnic Russian minorities. We surveyed 312 Ethnic Russians and 298 Georgians in Georgia; 277 Ethnic Russians and 317 Tajiks in Tajikistan. The studies used scales from the MIRIPS questionnaire. To test the three hypotheses of intercultural relations we followed a Structural Equation Modeling (SEM) approach. The multiculturalism hypothesis found partial support in all four groups in Georgia and Tajikistan. The contact hypothesis received partial support in Tajiks and in Ethnic Russians in Georgia and was not supported among Ethnic Russians in Tajikistan and Georgians. The integration hypothesis was fully supported in Tajiks and Ethnic Russians in Georgia, partially supported among Ethnic Russians in Tajikistan and was not supported among Georgians. The results obtained in these two countries are discussed taking into consideration the sociocultural contexts and recent history of wars and conflicts.
\end{abstract}

Keywords: ethnic minority, majority, intercultural relations, multiculturalism, contact, integration, post-Soviet, Georgia, Tajikistan.

\section{Introduction}

The period after the collapse of the USSR was characterized by not only political and socio-economic changes in the post-communist space, but also by changes in values, identification and disidentification with social categories, in the status of groups and models of intercultural relations. Research in a variety of post-communist countries, as well as in different multicultural regions of the Russian Federation, demonstrated very different paths towards the development of multicultural policy

The study was supported by the Russian Science Foundation (project № 15-18-00029).

${ }^{1}$ The names of the authors appear in alphabetical order. 
and practice (Lebedeva, Dimitrova, \& Berry, 2018). The task of nation-state building, and changes in the majority-minority status became a common trend for many post-communist countries and regions in Eastern Europe and Central Asia.

Studying intercultural relations in the post-Soviet space, we have identified three models of Post-Soviet development in terms of their dealing with cultural diversity (Lebedeva, 2018). The first one became known as the "nation-state model" as presented by Baltic countries (Estonia, Latvia, and Lithuania). They are typified by promoting the cultural, economic, demographic and political vitality of a core nation (Brubaker, 2009) and the forced assimilation of minorities. The second is called the "pragmatic model" as pesented by Azerbaijan and probably by Kazakhstan and Kirgizstan. This model is based on economic interests, and where cultural diversity is not a problem. The third and the most dramatic model is called "post-conflict model" presented by Georgia and Tajikistan. In these countries cultural diversity has been sharply reduced during wars and conflicts.

The goal of this study was to evaluate three hypotheses of intercultural relations: multiculturalism, contact and integration (Berry, 2017) among majority members and the ethnic Russian minority group in two countries, which represent the post-conflict model: Georgia and Tajikistan. The three hypotheses of intercultural relations are adapted to the contexts of these two countries and are presented below.

1. The multiculturalism hypothesis:

1a. The higher the perceived security among the ethnic Russian minority, the higher their support of multicultural ideology, ethnic tolerance and preference for integration and assimilation.

1b. The higher the perceived security among the ethnic majority (Georgians and Tajiks), the higher their support of multicultural ideology, ethnic tolerance and preference for integration and assimilation.

2. The contact hypothesis:

2a. The higher the intensity of friendly contacts between the ethnic Russian minority and the ethnic majority (Georgians and Tajiks), the higher their level of ethnic tolerance, and their preference for integration and assimilation.

$2 \mathrm{~b}$. The higher the intensity of friendly contacts of the ethnic majority (Georgians and Tajiks) with members of ethnic minority (Russians), the higher their level of ethnic tolerance and their preference for integration and assimilation.

3. The integration hypothesis:

3a. The higher the preference for the acculturation strategy of integration among the ethnic Russian minority, the higher their levels of life satisfaction, selfesteem, and sociocultural adaptation.

$3 \mathrm{~b}$. The higher the preference for integration expectation among members of the ethnic majority (Georgians and Tajiks), the higher their levels of life satisfaction and self-esteem.

Based on the results of previous research that highlighted the important role of assimilation in intercultural relations and mutual adaptation of migrants/ethnic minority and host society/ethnic majority groups (Berry, 2017; Jasinskaja-Lahti, Horenczyk, \& Kinunen, 2011; Kus-Harbord \& Ward, 2015; Lebedeva, Tatarko, \& 
Berry, 2016a; Lebedeva, Galyapina, Lepshokova, \& Ryabichenko, 2017), we tested some additional relationships for assimilation as well.

In previous studies it was found that preference for assimilation is positively related to life satisfaction (Lepshokova \& Tatarko, 2016; Ryabichenko \& Lebedeva, 2016) and sociocultural adaptation, but negatively related to selfesteem (Galyapina \& Lebedeva, 2016; Ryabichenko \& Lebedeva, 2016). Based on the above, we formulated the following hypothesis:

4. The assimilation hypothesis:

The higher the preference for assimilation among the ethnic Russian minorities and the ethnic majorities in Georgia and Tajikistan, the higher their life satisfaction, the lower their self-esteem and the higher the minorities' sociocultural adaptation.

\section{Measures}

The study used scales from the MIRIPS questionnaire (http://www.victoria.ac.nz/cacr/research/mirips) translated into Russian and adapted for use in Russia (Lebedeva \& Tatarko, 2009).

"Perceived Security" (3 items in Tajikistan, for example, "There is room for a variety of languages and cultures in Tajikistan", 5 items in Georgia, for example "We have to take steps to protect our cultural traditions from outside influences")

"Intercultural Contacts" (2 items "How many close Tajik/Georgian/Russian friends do you have?" and "How often to you meet with close Tajik/Georgian/ Russian friends".

"Multicultural Ideology" (5 items, for example, "We should recognize that cultural diversity is a fundamental characteristic of Tajik/Georgian society").

"Tolerance" (3 items, for example, "We should promote equality among all groups, regardless of their racial or ethnic origin").

"Acculturation Strategies" (for ethnic Russian minorities): integration (4 items, for example, 'It is important to me to be fluent in both Tajik/Georgian and Russian languages'); assimilation (4 items, for example, "I prefer social activities that involve Tajiks/Georgians only").

"Acculturation Expectations" (for the Tajik/Georgian majority): integration (4 items, for example, "Russians should be fluent in both Tajik/Georgian and Russian languages"); assimilation (4 items, for example, "Russians should prefer social activities that involve Tajiks/Georgians only").

"Self Esteem" (4 items, for example, "On the whole, I am satisfied with myself") (Rosenberg, 1965).

"Life Satisfaction" (4 items, for example, "In most ways my life is close to my ideal") (Diener, Emmons, Larsen, \& Griffin, 1985).

"Sociocultural Adaptation" (for ethnic Russian minorities) (7 items in Tajikistan, for example, "How much difficulty you experience, living in Tajikistan, in relating to members of the opposite sex", 11 items in Georgia, for example "How much difficulty you experience, living in Georgia, accurately interpreting and responding to other people's gestures and facial expressions") (Wilson, 2013). 


\section{Data processing}

We used the following methods of data processing: descriptive statistics and Cronbach's $\alpha$. To test the three hypotheses of intercultural relations we followed a Structural Equation Modeling (SEM) approach. Four path analyses were performed with two ethnic majority groups (Georgians, Tajiks) and two ethnic minority groups (Russians) separately using SPSS AMOS 20 software. Multivariate analysis of variance (MANOVA) was used to examine the differences between means of the used scales' scores across the different groups.

We present the two studies in the two regions sequentially one after the other.

\section{Study 1. Mutual Intercultural Relations between Georgians and Ethnic Russians in Georgia}

\section{Sociocultural context of Georgia}

Before the collapse of the USSR, Georgia was one of the most multiethnic regions of the South Caucasus. However, even at the time when Georgia was a part of the USSR, the popular primordial doctrines expressed in the slogan "Georgia for Georgians" prevailed among Georgian intellectuals, which led to the growing movement in support of the independence of the Republic in the late 1980s (Berglund, 2016). Therefore, after the declaration of Georgia's independence in 1991, ethnic minorities found themselves in a country "ruled by and for ethnic Georgians" (Ibid, p. 2) that in turn led to changes in self-determination among ethnic minorities members.

Two regions of Georgia (Abkhazia and South Ossetia) were inhabited mainly by ethnic minorities who proclaimed their independence at the beginning of 1990s. There were armed conflicts between Georgian and South Ossetian forces (in 1991-1992), and between Georgian and Abkhazian forces (in 1992-1994). These conflicts ended with Georgia losing control over these two regions. Conflicting sides were divided by Peacekeeping Forces on the basis of international agreements. These forces were formed by Russia, Georgia and Ossetia in South Ossetia and by the CIS countries in Abkhazia. The long period of "increasing tensions, provocations and incidents" had "deep roots in the history of the region, in peoples' national traditions and aspirations as well as in age-old perceptions or rather misperceptions of each other, which were never mended and sometimes exploited" (Independent International Fact Finding Mission on the Conflict in Georgia, 2009, p. 11). This culminated in the "five-day war" in 2008 that formally started with Georgia's attacking the capital of South Ossetia. The attack provoked an armed conflict between Georgia and Russia and ended in the secessions of South Ossetia and Abkhazia from Georgia. Currently there are no direct diplomatic relations between Georgia and Russia.

Political tensions and economic difficulties in the country resulted in decreased numbers of ethnic minorities from $29.9 \%$ of the total population in 1989 down to $16.2 \%$ in 2002 due emigration, as well as "de facto secessions" of two regions (South 
Ossetia and Abkhazia) (Nilsson \& Popjanevski, 2009, p. 8; Metreveli, Nilsson, Popjanevski, \& Yakobashvili, 2009; Sabanadze, 2011). The number of ethnic Russians in Georgia decreased from $6.3 \%$ to $1.5 \%$ during this period. In 2014, Russians were the third largest minority group after Azerbaijanis and Armenians, accounting for only about 26.5 thousand people or $0.7 \%$ of the population. More than half of all Russian Georgians live in Tbilisi (GeoStat, 2016).

The Russian language still remains the language of interethnic communication, but efforts are being made to replace this status with English, and this replacement is considered as a symbol of the country's European orientation (Sherouse, 2017).

The armed territorial conflicts and Russia's military and political support to South Ossetia and Abkhazia during these conflicts greatly influence the nature of intercultural relations, since many issues relating to ethnic minorities are often viewed through the prism of these conflicts. For Georgia, the attitude towards minorities is primarily a matter of national security (Sabanadze, 2011). Therefore, minorities are often seen as sources of potential threat (Sabanadze, 2011; Ulasiuk, 2013) that hinders the consolidation of society (Vardanyan, 2010). Therefore, despite the declaration of a state policy of integration, it is often equated with assimilation and 'Georgianization', with a move towards a monoethnic society by the emigration of, and the gradual assimilation of, ethnic minorities (Ibid.).

\section{Participants and procedure}

The sample included 610 respondents: 298 ethnic Georgians and 312 ethnic Russians. A snowball sampling procedure was used. Russians and Georgians filled out the questionnaire in their native languages (Russian and Georgian subsequently). A description of the sample is presented in Table 1.

\section{Results of the study 1}

Descriptive statistics including means, standard deviations, reliability coefficients of measures and the results of MANOVA are presented in Table 2.

The MANOVA with ethnicity as the independent variable, and perceived security, intercultural contacts, multicultural ideology, tolerance, integration, assimilation, self-esteem and life satisfaction as dependent variables showed a significant multivariate main effect: Wilks' $\lambda=.595, \mathrm{~F}(8,601)=51.223, p<.001, \eta^{2}=.405$. ANOVAs on all individual measures were also significant (see Table 2). The scores

Table 1

Gender and Age Characteristics of the Sample

\begin{tabular}{|l|c|c|c|c|c|c|c|}
\hline \multirow{2}{*}{ Respondents } & \multirow{2}{*}{$\mathbf{N}$} & \multicolumn{2}{|c|}{ Gender characteristics } & \multicolumn{4}{c|}{ Age characteristics } \\
\cline { 3 - 9 } & & Male & Female & Min. & Max. & M & SD \\
\hline Ethnic Russians & 312 & $102(32.7 \%)$ & $210(67.3)$ & 14 & 67 & 31.11 & 14.57 \\
\hline Georgians & 298 & $50(16.8 \%)$ & $248(83.2)$ & 15 & 64 & 30.45 & 14.11 \\
\hline
\end{tabular}


Table 2

A Comparison of Means for Samples of Ethnic Russians and Georgians in Georgia (Max. 5 Points)

\begin{tabular}{|c|c|c|c|c|c|c|}
\hline & \multicolumn{2}{|c|}{ Ethnic Russians } & \multicolumn{2}{|c|}{ Georgians } & \multirow{2}{*}{$F(1,591)$} & \multirow{2}{*}{ Partial $\eta^{2}$} \\
\hline & $\mathrm{M}(\mathrm{SD})$ & $\alpha$ & $\mathrm{M}(\mathrm{SD})$ & $\alpha$ & & \\
\hline Perceived Security & $3.51(0.60)$ & .51 & $2.93(0.71)$ & .52 & 119.33 & $.164 * * *$ \\
\hline Intercultural Contacts & $3.86(0.82)$ & .83 & $4.21(0.84)$ & .59 & 31.68 & $.050 * * *$ \\
\hline Multicultural Ideology & $3.98(0.59)$ & .53 & $3.82(0.73)$ & .58 & 9.40 & $.015^{* *}$ \\
\hline Tolerance & $3.90(0.85)$ & .48 & $3.08(1.05)$ & .54 & 113.53 & $.157^{* * *}$ \\
\hline Integration & $4.33(0.54)$ & .62 & $4.07(9.79)$ & .68 & 22.54 & $.036^{* * *}$ \\
\hline Assimilation & $1.67(0.54)$ & .67 & $2.15(9.92)$ & .79 & 62.81 & $.094^{* * *}$ \\
\hline Self-Esteem & $4.12(0.53)$ & .70 & $4.01(9.67)$ & .77 & 4.54 & $.007^{*}$ \\
\hline Life Satisfaction & $2.73(0.72)$ & .73 & $3.28(9.95)$ & .84 & 64.77 & $.096^{* * *}$ \\
\hline Sociocultural Adaptation ${ }^{c}$ & $3.96(0.61)$ & .88 & & & & \\
\hline
\end{tabular}

${ }^{*} p<0.05,{ }^{* *} p<0.01,{ }^{* * *} p<0.001$.

${ }^{\mathrm{c}}$ Measure of sociocultural adaptation is used in the group of ethnic Russians only.

on perceived security, multicultural ideology, ethnic tolerance, integration and selfesteem are higher in the sample of Russians compared with Georgians. Georgians have higher scores on intercultural contacts, assimilation and life satisfaction.

Results of the path analysis in the two groups are presented in Figure 1.

Among ethnic Russians perceived security positively related to ethnic tolerance $(\beta=.14, p<.05)$ and integration $(\beta=.11, p<.05)$, negatively related to assimilation $(\beta=-.18, p<.01)$ and did not relate to multicultural ideology. In the group of ethnic Georgians, perceived security positively related to integration $(\beta=.21$, $p<.001)$ and to multicultural ideology $(\beta=.23, p<.001)$, but didn't relate to tolerance and assimilation expectation.

Intercultural contacts negatively related to ethnic tolerance $(\beta=-.13, p<.05)$ and assimilation $(\beta=-.20, p<.001)$ in the majority group. Intercultural contacts positively related to both integration $(\beta=.13, p<.05)$, and assimilation $(\beta=.22$, $p<.001$ ), but didn't significantly relate to ethnic tolerance in the Russian minority.

The relationship of integration and sociocultural adaptation of Russians was positive $(\beta=.19, p<.001)$, as well as for self-esteem $(\beta=.19, p<.001)$ and life satisfaction $(\beta=.15, p<.01)$, while the latter two relationships were nonsignificant among Georgians.

Assimilation negatively related to self-esteem of Georgians $(\beta=-.14, p<.05)$ that is along with the assimilation hypothesis, but at the same time it negatively related to sociocultural adaptation of ethnic Russians $(\beta=-.14, p<.05)$ that contradicts this hypothesis. 
Figure 1

Results of the Path Analysis for Three Hypotheses of Intercultural Relations for Ethnic Russians/Georgians

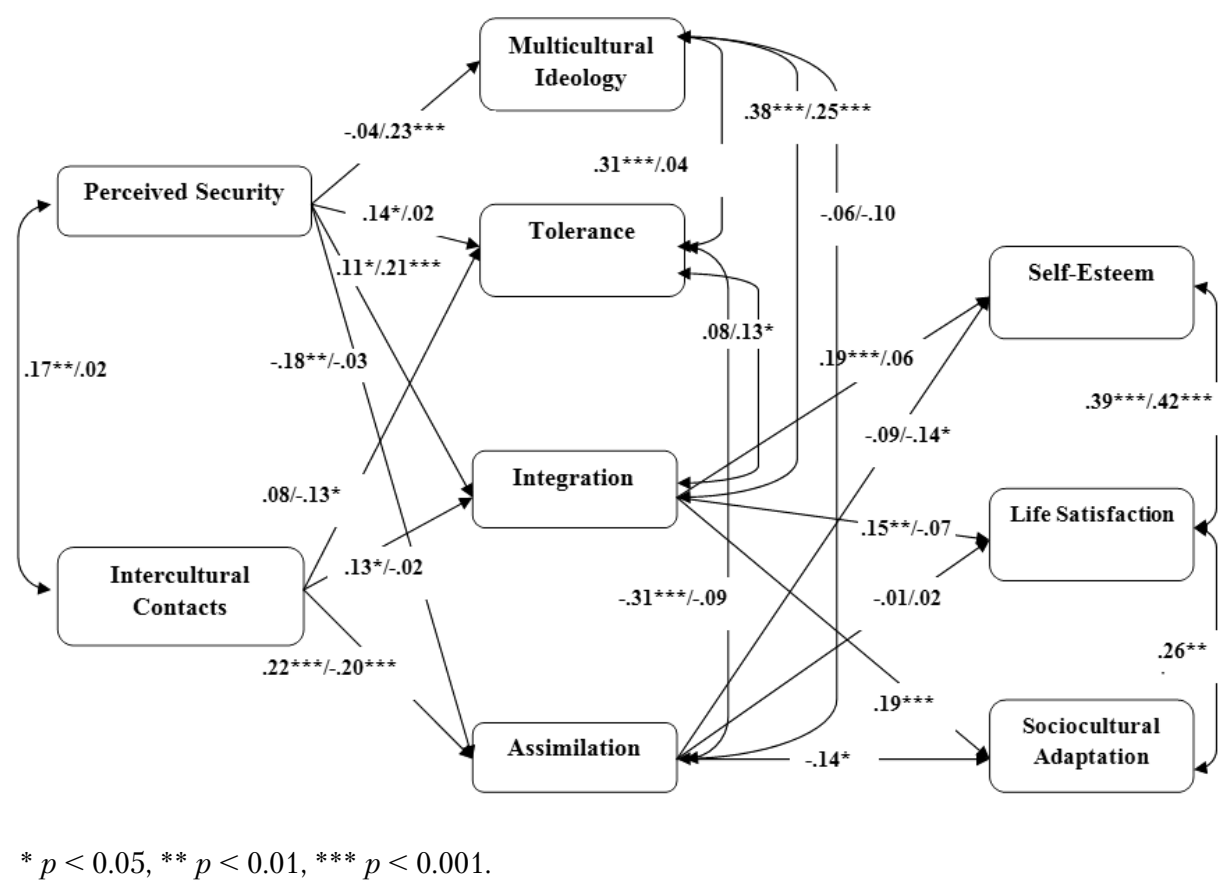

Note. Acculturation strategies of integration and assimilation were used in the sample of Russian minority, integration and assimilation expectations were used in the sample of Georgian majority.

Indicators of the models: $\chi^{2} / \mathrm{df}=1.84 / 1.93 ; \mathrm{CFI}=.97 / .97 ; \mathrm{RMSEA}=.05 / .06 ; \mathrm{PCLOSE}=.416 / .362$.

\section{Study 2. Mutual Intercultural Relations between Tajiks and Ethnic Russians in Tajikistan}

\section{Sociocultural context of Tajikistan}

Tajikistan is a former republic of the USSR with a mainly rural population. Tajikistan can be called the poorest country in the CIS, according to The Richest Countries in the World (Gregson, 2016), with 50\% of the total GDP of the country consisting of remittances from Tajik labor migrants in Russia (Sarabekov, 2016). The population of Tajikistan is mostly Muslims (approximately 95\% Sunni and 3\% Shia). The next largest religious community is Russian Orthodox. After the collapse of the USSR the numbers of the largest ethnic minorities (ethnic Uzbeks and ethnic Russians) in Tajikistan decreased respectively from $23.5 \%$ and $7.63 \%$ of the whole population in 1989 to $13.9 \%$ and $0.46 \%$ in 2010, respectively (Vsesoyuznaya perepis' naseleniya..., 2015; Mukhammadieva, 2013). At present, the number of 
ethnic Russians (residing mainly in in Dushanbe, the capital of Tajikistan) is declining rapidly (Mukhammadieva, 2013).

Since the Tajik civil war of 1989 there has been a mass exodus of ethnic Russians and Russian-speakers. The conflict began between the Islamic-democratic opposition and the Tajik communist leaders. The communist regime was associated with Ethnic Russians in Tajik society. The nationalists blamed the former USSR dominant group (ethnic Russians) for all their difficulties (drought, earthquakes, crop failure etc.). The war caused interethnic conflicts in the Ferghana Valley and the persecution of the Russian population in Dushanbe and other cities. This all led to the fact that many Russian civilians were killed, and the survivors were forced to flee. As a result of the civil war, 60-200 thousand people were missing, and one million people left the country, including over 300 thousand Russians (Norin, 2016). The ethnic Russians, being the most numerous ethnic minority before the war, practically disappeared by the end of the civil war in Tajikistan (Sitnyanskiy, 2011). The official language of Tajikistan is Tajik. The Constitution mentions Russian as the "language for interethnic communication". The Russian language remains the language of culture and science in Tajikistan, since specialised terminology has not yet been developed in the Tajik language (Letnyakov, 2015). Education in Russian is considered prestigious in Tajikistan (Dubovitskaya, 2009).

Today, the population of Tajikistan is growing rapidly due to the high birth rate among Tajiks, while the number of ethnic minorities is decreasing causing a rapid national transition to mono-ethnicity.

\section{Participants and procedure}

The sample included 317 Tajiks and 277 ethnic Russians. A snowball technique for sampling was used. We asked Tajik and Russian university students from Russian-Tajik (Slavic) University and high school students from Russian-language schools to fill out questionnaires by themselves as well as to distribute them among their friends and parents. Respondents filled out questionnaires in Russian. A socio-demographic description of the sample is presented in Table 3.

\section{Results of the study 2}

Descriptive statistics including means, standard deviations, reliability coefficients of measures and the results of MANOVA are presented in Table 4.

Table 3

Gender and Age Characteristics of the Sample

\begin{tabular}{|l|c|c|c|c|c|c|c|}
\hline \multirow{2}{*}{ Respondents } & \multirow{2}{*}{$\mathbf{N}$} & \multicolumn{2}{|c|}{ Gender characteristics } & \multicolumn{4}{c|}{ Age characteristics } \\
\cline { 3 - 8 } & & Male & Female & Min. & Max. & M & SD \\
\hline Ethnic Russians & 277 & $90(33 \%)$ & $187(67 \%)$ & 14 & 73 & 31.58 & 16.17 \\
\hline Tajiks & 317 & $110(35 \%)$ & $207(65 \%)$ & 15 & 63 & 30.60 & 14.81 \\
\hline
\end{tabular}


A Comparison of Means for Samples of Ethnic Russians and Tajiks in Tajikistan (Max. 5 Points)

\begin{tabular}{|c|c|c|c|c|c|c|}
\hline & \multicolumn{2}{|c|}{ Ethnic Russians } & \multicolumn{2}{|l|}{ Tajiks } & \multirow{2}{*}{$F(1,591)$} & \multirow{2}{*}{ Partial $\eta^{2}$} \\
\hline & $\mathrm{M}(\mathrm{SD})$ & $\alpha$ & $\mathrm{M}(\mathrm{SD})$ & $\alpha$ & & \\
\hline Perceived Security & $3.30(0.71)$ & .61 & $3.91(0.85)$ & .51 & 90.79 & $.132 * * *$ \\
\hline Intercultural Contacts & $4.10(0.85)$ & .62 & $4.18(0.96)$ & .71 & 1.05 & .002 \\
\hline Multicultural Ideology & $3.90(0.80)$ & .59 & $3.99(0.77)$ & .61 & 1.70 & .003 \\
\hline Tolerance & $4.26(0.80)$ & .54 & $3.69(0.72)$ & .54 & 88.22 & $.129^{* * *}$ \\
\hline Integration & $4.13(0.87)$ & .72 & $3.97(0.80)$ & .64 & 6.04 & $.010^{*}$ \\
\hline Assimilation & $1.95(0.81)$ & .72 & $2.39(0.97)$ & .74 & 35.99 & $.057^{* * *}$ \\
\hline Self-Esteem & $4.15(0.72)$ & .79 & $4.26(0.66)$ & .75 & 3.37 & .006 \\
\hline Life Satisfaction & $3.27(0.96)$ & .80 & $3.87(0.83)$ & .76 & 67.91 & $.122 * * *$ \\
\hline Sociocultural Adaptation $^{c}$ & $3.50(0.84)$ & .84 & & & & \\
\hline
\end{tabular}

${ }^{*} p<0.05, * * p<0.01, * * * p<0.001$.

${ }^{\mathrm{c}}$ Measure of sociocultural adaptation is used in the group of ethnic Russians only.

The MANOVA with ethnicity as the independent variable, and perceived security, intercultural contacts, multicultural ideology, tolerance, integration, assimilation, self-esteem and life satisfaction as dependent variables showed a significant multivariate main effect: Wilks' $\lambda=.706, F(8,589)=30.632, p<.001, \eta^{2}=.294$. ANOVAs on the individual measures were also significant for perceived security, tolerance, integration, assimilation and life satisfaction (see Table 4). The scores on tolerance and integration were significantly higher in the sample of ethnic Russians than in the sample of Tajiks. The scores on perceived security, assimilation and life satisfaction were significantly higher in the sample of Tajiks than in the sample of ethnic Russians.

Results of the path analysis in the two groups are presented in Figure 2.

Perceived security positively related to multicultural ideology $(\beta=.16 / .15, p<.01)$ and integration $(\beta=.18 / .14, p<.01)$, but was not related to tolerance in either samples of ethnic Russians and Tajiks. We also found a positive relationship between perceived security and assimilation among the Tajiks $(\beta=.13, p<.05)$.

In both groups intercultural contacts negatively related to ethnic tolerance $(\beta=-.13 / .-13, p<.05)$ and were not related to the assimilation preferences. Among Tajiks contacts positively related to integration $(\beta=.15, p<.01)$. We also found a positive correlation between perceived security and intercultural contacts in the sample of ethnic Russians.

The relationships between integration and well-being were positive for selfesteem $(\beta=.22, p<.001)$ and life satisfaction $(\beta=.14, p<.05)$ in the group of Tajiks. The relationships of integration were positive for self-esteem $(\beta=.26, p<.001)$, but 
Figure 2

Results of the Path Analysis for Three Hypotheses of Intercultural Relations for Ethnic Russians/Tajiks

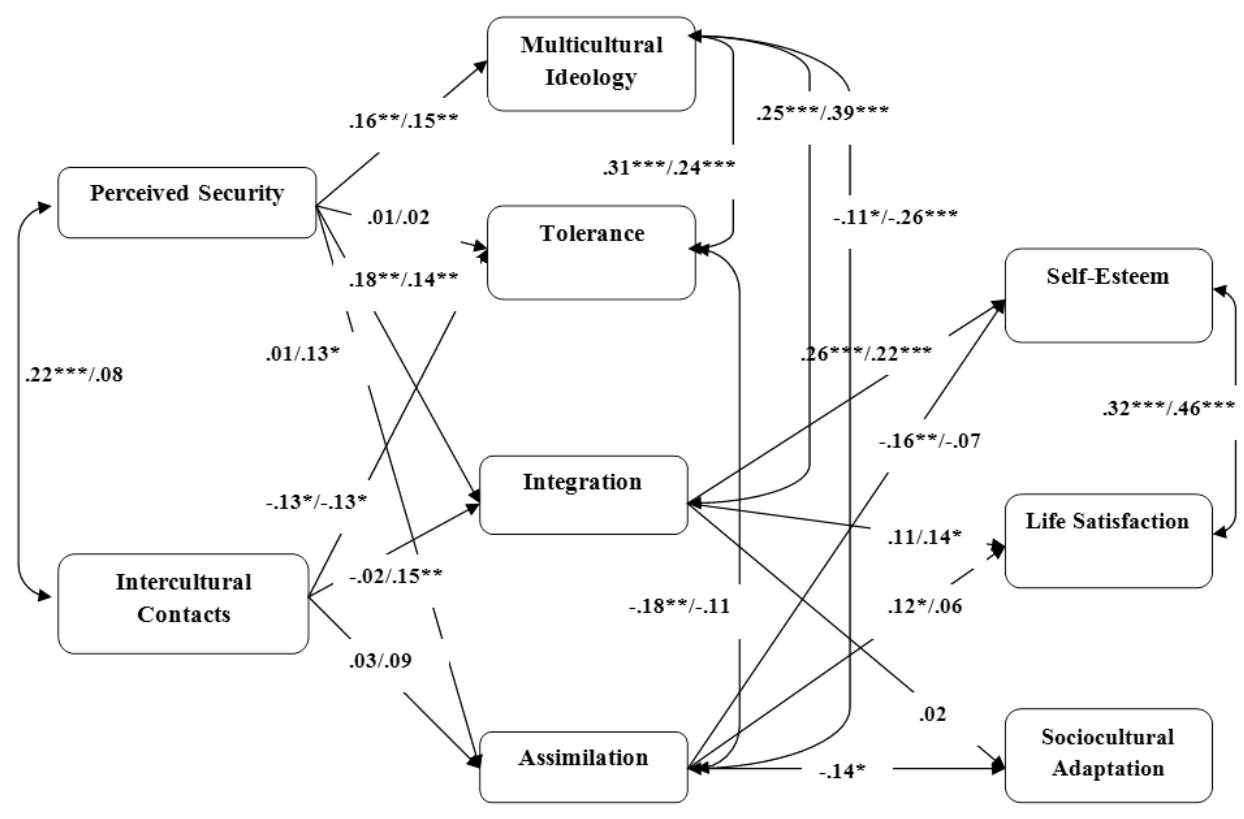

${ }^{*} p<0.05,{ }^{* *} p<0.01,{ }^{* * *} p<0.001$.

Note. Acculturation strategies of integration and assimilation were used in the sample of Russian minority, integration and assimilation expectations were used in the sample of Tajiks majority.

Indicators of the models: $\chi^{2} / \mathrm{df}=2.54 / 1.64 ; \mathrm{CFI}=.97 / .99 ; \mathrm{RMSEA}=.075 / .042 ; \mathrm{PCLOSE}=.125 / .546$.

nonsignificant for life satisfaction and sociocultural adaptation among the ethnic Russians.

Assimilation strategy negatively related to self-esteem $(\beta=-.16, p<.01)$ and sociocultural adaptation $(\beta=-.14, p<.05)$ among the ethnic Russians, but positively related to life satisfaction $(\beta=.12, p<.05)$.

\section{General discussion}

The aim of these two studies was to test the three hypotheses of intercultural relations in groups of the Russian ethnic minority and the majorities in Georgia and Tajikistan.

The multiculturalism hypothesis found partial support in both groups in Georgia. Perceived security of ethnic Russians was positively associated with integration and negatively - with assimilation. Based on this result we could argue that security enhances the orientation of the Russian minority to preserve its own culture contacting with a larger society. Perceived security was positively related to ethnic 
tolerance and friendly contacts with Georgians among Russians as well. A probable explanation might be that for such a small group as Russians in Georgia $(0.7 \%$ of population), the willingness to be open to other groups and to develop personal friendships is possible when there is no threat to their group. For Georgians, security is linked to integration and multicultural ideology, but not to ethnic tolerance. It might be a result of previous territorial conflicts that aggravated the sense of threat from ethnic minorities among Georgians, as well as nationalist rhetoric that existed in the country for a long time (Berglund, 2016; Sabanadze, 2011; Ulasiuk, 2013), which affected the lower level of ethnic tolerance in comparison with Russians. Their fears are related to the integrity of the country which has been disrupted by ethnically-related conflicts. Under these conditions, only a sense of security can ensure the majority's loyalty to cultural diversity in the country and their orientation towards the integration of minorities.

In Tajikistan the multiculturalism hypothesis found partial support in both groups. Perceived security among both ethnic Russians and Tajiks was positively associated with multicultural ideology and integration preferences. These results are consistent with data obtained from other countries (e.g., Berry, Phinney, Sam, \& Vedder, 2006) where sense of security was positively associated with positive intercultural attitudes and supporting of multicultural ideology. We also found that among Tajiks security perception was positively related to assimilation expectation for ethnic Russians. These findings are consistent with results obtained in the Kabardino-Balkar Republic (KBR), Russia, by Z. Lepshokova and A. Tatarko (2016). The authors explained this phenomenon through the group-threat theory (Bobo, 1999) stating that when a minority group challenges the social position of a majority group by maintaining their own culture, the majority group feels threatened and prefers the assimilation of the minority (Davies, Steele, \& Markus, 2008; Tip et al., 2012).

The contact hypothesis was partially supported only in the group of ethnic Russians in Georgia. Intercultural contacts in this group are related to both integration and assimilation. At the same time, we did not find a significant relationship of intercultural contacts with ethnic tolerance among ethnic Russians, but a negative relationship of intercultural contacts with ethnic tolerance among Georgians was revealed. In addition, there are no significant relations of contacts to integration expectation in the group of Georgians. This result is consistent with the results found for ethnic Russians and Latvians in Latvia (Lebedeva, Tatarko, \& Berry, 2016b; Lebedeva \& Tatarko, 2017) and for ethnic Russians in Lithuania (Ryabichenko, 2017). The contact hypothesis might be confirmed where certain conditions are met, such as the equal social and economic status of the interacting groups (Berry, 2017) that is difficult to achieve with the majority dominating in all areas of life.

The contact hypothesis in Tajikistan was partially supported in the group of Tajiks and wasn't supported in the group of ethnic Russians. The results of our study demonstrated that intercultural contacts negatively related to ethnic tolerance among members of both samples in Tajikistan. We suppose that the absence of optimal conditions for contact to reduce prejudice (equal status, cooperation 
rather than competition, common goals, and authority support) (Allport, 1954) in Tajikistan are the reasons why intercultural contacts did not predict ethnic tolerance in both samples in this country. But it is also important to note that among Tajiks their friendly intercultural contacts with Russians resulted in a preference for Russians' integration in Tajikistan. Among Russians, intercultural contacts positively correlated with their perceived security as it was in Georgia. Similar results were obtained in the Republic of North Ossetia-Alania (Lebedeva \& Galyapina, 2016): the Russian's friendly contacts with the Ossetians had a significant and positive relationship with their perceived security. The difference was that in North Ossetia-Alania contacts were positively connected with ethnic tolerance in both groups, which is not true for Georgia and Tajikistan.

The integration hypothesis was fully confirmed among Russians in Georgia: the integration strategy is positively related to their self-esteem, life satisfaction and socio-cultural adaptation. However, we failed to confirm the hypothesis in the Georgian sample. A similar result was obtained in Azerbaijan, where, as in Georgia, the share of the Russian minority is very small; the psychological well-being of the majority does not depend on attitudes towards minorities (Galyapina \& Lebedeva, 2017). At the same time, assimilation is negatively linked to the self-esteem of Georgians, and intercultural contacts in the group of Georgians have proven to be an obstacle to assimilation, indicating a lack of aspiration to assimilate Russians among the Georgian majority.

In Tajikistan the integration hypothesis was fully confirmed in the Tajiks: their expectation of integration of ethnic Russians is positively related to self-esteem and life satisfaction of Tajiks. This hypothesis was partially supported in the group of ethnic Russians: their integration preference was positively related to their selfesteem. Our results are consistent with previous research (Hui, Chen, Leung, \& Berry, 2015; Jasinskaja-Lahti et al., 2011).

The assimilation hypothesis was partially supported in the sample of ethnic Georgians: their assimilation expectations negatively related to their self-esteem. Negative relationship between assimilation and sociocultural adaptation of ethnic Russians contradicts the results obtained in previous studies (e.g., Ward \& Rana-Deuba, 1999).

The assimilation hypothesis in Tajikistan was partially supported in the sample of ethnic Russians, but not supported in the sample of Tajiks. Assimilation was negatively associated to the self-esteem and socio-cultural adaptation, but positively related to life satisfaction of ethnic Russians. Some studies found the same relationships. In a study of interethnic relations in the KBR assimilation strategy negatively related to self-esteem among the ethnic Russian minority (Lepshokova, 2012), in a study of intercultural relations among migrants from Caucasus and Russians in Moscow the assimilation strategy of migrants negatively related to sociocultural adaptation and positively related to their life satisfaction (Lebedeva et al., 2016a).

\section{Conclusion}

In Georgia, both contact hypothesis and integration hypothesis were not confirmed among Georgians. It can be assumed that this result reflects unfavorable 
attitudes of the majority towards Russians associated with the threat to the integrity of Georgia, as experienced in the secession of Abkhazia and South Ossetia.

In Tajikistan we found that intercultural contacts did not predict tolerance in the ethnic minority and majority groups. A large cultural distance, religious differences, the presence of a history of conflict contributed to the fact that both Tajiks and Russians perceive each other as "aliens". At the same time the integration hypothesis is fully supported in the Tajik sample and partially supported among Russians. Both groups regard assimilation as an alternative strategy for the ethnic Russian minority: among Tajiks perceived security predicts preference for assimilation of Russians, while among Russians assimilation was significantly and positively associated with their life satisfaction. Probably this is a nearest future for reducing the ethnic Russian minority in the countries with a post-conflict past.

We can conclude that the post-conflict model of intercultural relations in the post-Soviet space is characterized by some specific patterns of the relationships between psychological variables: perceived security and intercultural contacts are closely connected with each other; contacts do not promote ethnic tolerance among both majorities and minorities. Such a complex interplay of security, contacts and tolerance reflects the impact of past conflicts on the psychology of intercultural relations in these countries and requires taking it into consideration.

\section{References}

Allport, G. W. (1954). The nature of prejudice. Garden City, NY: Doubleday.

Berglund, C. (2016). "Forward to David the Builder!" Georgia's (re)turn to language-centered nationalism. Nationalities Papers, 44(4), 1-21. doi:10.1080/00905992.2016.1142519

Berry, J. W. (2017). Introduction to Mutual intercultural relations. In J. W. Berry (Ed.), Mutual intercultural relations (pp. 1-33). Cambridge: Cambridge University Press. doi:10.1017/ 9781316875032.001

Berry, J. W., Phinney, J. S., Sam, D. L, \& Vedder, P. (2006). Immigrant youth: Acculturation, identity, and adaptation. Applied Psychology, 55, 303-332. doi:10.1111/j.1464-0597.2006.00256.x

Bobo, L. D. (1999). Prejudice as group position: Microfoundations of a sociological approach to racism and race relations. Journal of Social Issues, 55(3), 445-472. doi:10.1111/0022- 4537.00127

Brubaker, R. (2009). Ethnicity, race and nationalism. Annual Review of Sociology, 35, 21-42. doi:10.1146/annurev-soc-070308-115916

Davies, P. G., Steele, C. M., \& Markus, H. R. (2008). A nation challenged: The impact of foreign threat on America's tolerance for diversity. Journal of Personality and Social Psychology, 95(2), 308-318. doi:10.1037/0022-3514.95.2.308

Diener, E., Emmons, R. A., Larsen, R. J., \& Griffin, S. (1985). The Satisfaction with Life Scale.Journal of Personality Assessment, 49, 71-75. doi:10.1207/s15327752jpa4901_13

Dubovitskaya, I. (2009). Rol' russkogo yazyka na territorii Sredney Azii: vzglyad iz Tadzhikistana [The role of the Russian language in the territory of Central Asia: a view from Tajikistan]. EuroAsia, 1. Retrieved from http://www.promreview.net/moskva/rol-russkogo-yazyka-na-territoriisrednei-aziivzglyad-iz-tadzhikistana?page $=0,0$ (in Russian) 
Galyapina, V. N., \& Lebedeva, N. M. (2016). Is multiculturalism in Russia possible? Intercultural relations in North Ossetia-Alania. Psychology in Russia: State of the Art, 9(1), 24-40. doi:10.11621/pir.2016.0102

Galyapina, V. N., \& Lebedeva, N. M. (2017). Mezhkul'turnye otnosheniya mezhdu azerbajdzhancami i russkimi v post-sovetskom Azerbajdzhane [Intercultural relations between Azerbaijanis and Russians in Post-Soviet Azerbaijan]. In N. M. Lebedeva (Ed.), Mezhkul'turnye otnosheniya na postsovetskom prostranstve [Intercultural relations in the Post-Soviet space] (pp. 363-380). Moscow: Menedzher. (in Russian)

GeoStat. (2016). 2014 General Population Census: Main Results, National Statistics Office of Georgia, Tbilisi. Retrieved from http://geostat.ge/cms/site_images/_files/english/population/ Census_release_ENG_2016.pdf

Gregson, J. (2016, February). The richest countries in the world. Global Finance. Retrieved from http://www.gfmag.com/global-data/economic-data/richest-countries-in-the-world?page=12

Hui, B. P. H., Chen, S. X., Leung, C. M., \& Berry, J. W. (2015). Facilitating adaptation and intercultural contact: The role of integration and multicultural ideology in dominant and nondominant groups. International Journal of Intercultural Relations, 45, 70-84. doi:10.1016/ j.ijintrel.2015.01.002

Independent International Fact Finding Mission on the Conflict in Georgia. (2009). Report (Vol. 1). Retrieved from https://www.echr.coe.int/Documents/HUDOC_38263_08_Annexes_ENG.pdf

Jasinskaja-Lahti, I., Horenczyk, G., \& Kinunen, T. (2011). Time and context in the relationship between acculturation attitudes and adaptation among Russian-speaking immigrants in Finland and Israel. Journal of Ethnic and Migration Studies, 37(9), 1423-1440. doi:10.1080/1369183X.2011.623617

Kus-Harbord, L., \& Ward, C. (2015). Ethnic Russians in post-Soviet Estonia: Perceived devaluation, acculturation, well-being, and ethnic attitudes. International Perspectives in Psychology: Research, Practice, Consultation, 4(1), 66-81. doi:10.1037/ipp0000025

Lebedeva, N. M. (2018). Multiculturalism and intercultural relations in the Post-Soviet space. A keynote presentation at the 24th International Congress of the International Association for CrossCultural Psychology (IACCP 2018). Guelph, Canada, 1-5 July, 2018.

Lebedeva, N., Dimitrova, R., \& Berry, J. (2018). Changing values and identities in Post-Communist world. Cham: Springer International Publishing. doi:10.1007\%2F978-3-319-72616-8

Lebedeva, N., \& Galyapina, V. (2016). Is multiculturalism in Russia possible? Intercultural relations in North Ossetia-Alania. Psychology in Russia: State of the Art, 9(1), 24-40. doi:10.11621/pir.2016.0102

Lebedeva, N., Galyapina, V., Lepshokova, Z., \& Ryabichenko, T. (2017). Intercultural relations in Russia. In J. W. Berry (Ed.), Mutual intercultural relations in plural societies (pp. 34-58). Cambridge: Cambridge University Press. doi:10.1017/9781316875032.002

Lebedeva, N. M., \& Tatarko, A. N. (Eds.). (2009). Strategii mezhkulturnogo vzaimodeystviya migrantov $i$ naseleniya Rossii: Sbormik nauchnykh statey [Strategies for the intercultural interaction of migrants and the population of Russia: A collection of scientific articles]. Moscow: RUDN University. (in Russian)

Lebedeva, N. M., \& Tatarko, A. N. (2017). Mezhkul'turnye otnosheniya latyshej i russkih v postsovetskoj Latvii [Intercultural relations between Latvians and Russians in Post-Soviet Latvia]. In N. M. Lebedeva (Ed.), Mezhkul'turnye otnosheniya na postsovetskom prostranstve [Intercultural relations on Post-Soviet space] (pp. 301-323). Moscow: Menedzher. (in Russian)

Lebedeva, N., Tatarko, A., \& Berry, J. W. (2016, a). Intercultural relations among migrants from Caucasus and Russians in Moscow. International Journal of Intercultural Relations, 52, 27-38. doi:10.1016/j.ijintrel.2016.03.001 
Lebedeva, N. M., Tatarko, A. N., \& Berry, J. (2016, b). Intercultural relations in Russia and Latvia: the relationship between contact and cultural security. Psychology in Russia: State of the Art, 9(1), 4156. doi:10.11621/pir.2016.0103

Lepshokova, Z. H. (2012). Strategii adaptatsii migrantov i ih psihologicheskoe blagopoluchie (na primere Moskvy i Severnogo Kavkaza) [Adaptation strategies of migrants and their psychological wellbeing (the case of Moscow and the North Caucasus)]. Moscow: Grifon. (in Russian)

Lepshokova, Z., \& Tatarko, A. (2016). Intercultural relations in Kabardino-Balkaria: Does integration always lead to subjective well-being? Psychology in Russia: State of the Art, 9(1), 56-73. doi:10.11621/pir.2016.0104

Letnyakov, D. E. (2015). Rol' russkogo yazyka v postsovetskoy Tsentral'noy Azii [The role of the Russian language in Post-Soviet Central Asia]. Politiya. Analiz. Khronika. Prognoz, 4(79), 100-115. Retrieved from http://politeia.ru/files/articles/rus/Politeia-2015-4(79)-Pages-001-198.pdf (in Russian)

Metreveli, E., Nilsson, N., Popjanevski, J., \& Yakobashvili, T. (2009). State approaches to national integration in Georgia: Trwo perspectives. Washington, DC: Silk Road Paper.

Mukhammadieva, B. Z. (Ed.). (2013). Monografiya i atlas Respubliki Tadzhikistan po dannym perepisi naseleniya $i$ zhilishchnogo fonda 2010 goda [A monograph and the atlas of the Republic of Tajikistan according to the 2010 population and housing census data]. Dushanbe: Agentstvo po statistike pri Prezidente Respubliki Tadzhikistan. (in Russian; in Tajik)

Nilsson, N., \& Popjanevski, J. (2009). State building dilemmas: The process of national integration in postrevolutionary Georgia. In E. Metreveli, N. Nillson, J. Popjanevski, \& T. Yakobashvili, State approaches to national integration in Georgia: Two perspectives (pp. 7-44). Washington, DC: Silk Road Paper.

Norin, E. (2016). Neznamenitaya voyna v Tadzhikistane: 1992-1997 [The unknown war in Tajikistan: 19921997]. Retrieved from https://pikabu.ru/story/voyna_v_tadzhikistane_chast_pervaya_glava_pervaya_3971940 (in Russian)

Rosenberg, M. (1965). Society and the adolescent self-image. Princeton, NJ: Princeton University Press. doi:10.1515/9781400876136

Ryabichenko, T. A. (2017). Russkie v litovskom kontekste: proverka trekh gipotez mezhkul'turnyh otnoshenij [Russians in the Lithuanian context: testing the three hypotheses of intercultural relations]. In N. M. Lebedeva (Ed.), Mezhkulturnye otnosheniya na postsovetskom prostranstve [Intercultural relations in the Post-Soviet space] (pp. 324-341). Moscow: Menedzher. (in Russian)

Ryabichenko, T., \& Lebedeva, N. (2016). Assimilation or integration: Similarities and differences between acculturation attitudes of migrants from Central Asia and Russians in Central Russia. Psychology in Russia: State of the Art, 9(1), 98-111. doi:10.11621/pir.2016.0107

Sabanadze, N. (2011). States, minorities and regional hegemons in the South Caucasus: Whose responsibility to protect. In F. Palermo, \& N. Sabanadze, (Eds.), National minorities in inter-state relations (pp. 165-183). Leiden/Boston: OSCE HCNM. doi:10.1163/ej.9789004175983.i-274.54

Sarabekov, J. (2016). Sovremennyy Tadzhikistan: vyzovy razvitiya [Modern Tajikistan: development challenges]. Astana-Almaty: Institut mirovoy ekonomiki i politiki pri Fonde Pervogo Prezidenta Respubliki Kazakhstan - Lidera Natsii. Retrieved from https://docplayer.ru/28306335Sovremennyy-tadzhikistan-vyzovy-razvitiya.html (in Russian)

Sherouse, P. (2017). The politics of Russian-Language film showings in Post-Soviet Georgia. Political and Legal Anthropology Reviewe, 40, 137-157. doi:10.1111/plar.12209

Sitnyanskiy, G. Y. (2011). Rossiya i Tsentral'naya Aziya: vmeste ili vroz'? Mezhetnicheskiye otnosheniya v Sredney Azii i Kazakhstane i Rossiya [Russia and Central Asia: together or apart? Interethnic 
relations in Central Asia and Kazakhstan and Russia]. Moscow: N.N. Miklukho-Maklai Institute of Ethnology and Anthropology of the RAS. (in Russian)

Tip, L. K., Zagefka, H., González, R., Brown, R., Cinnirella, M., \& Na, X. (2012). Is support of multiculturalism threatened by... threat itself? International Journal of Intercultural Relations, 36(1), 22-30. doi:10.1016/j.ijintrel.2010.09.011

Ulasiuk, I. (2013). National minorities and migration in Armenia, Azerbaijan, Belarus, Georgia, Moldova, Russia and Ukraine (CARIM-East Research Report 2013/33). San Domenico di Fiesole (FI), Italy: European University Institute. Retrieved from http://www.carim-east.eu/media/CARIMEast-RR2013-33.pdf

Vardanyan, T. (2010). Gruziya: identichnost' v politicheskikh programmakh i dejstvii [Georgia: the identities in political programs and in action]. 21-y Vek. Informatsionno-analiticheskij zhurnal [21st century. Informational and analytical journal], 3, 48-69. (in Russian)

Vsesoyuznaya perepis' naseleniya 1989 goda [All Union Population Census of 1989]. (2015). Demoscope Weekly, 651-652. Retrieved from http://www.demoscope.ru/weekly/ssp/ rus_nac_70.php?reg=50 (in Russian)

Ward, C. \& Rana-Deuba, A. (1999). Acculturation and adaptation revisited.Journal of Cross-Cultural Psychology, 30(4), 422-442. doi:10.1177/0022022199030004003

Wilson, J. (2013). Exploring the past, present and future of cultural competency research: The revision and expansion of the sociocultural adaptation construct (Unpublished doctoral dissertation). Victoria University of Wellington, Wellington, New Zealand.

John Widdup Berry - Emeritus Professor of Psychology, Queen's University, Canada; chief research fellow, International Scientific-Educational Laboratory for Socio-Cultural Research, Expert Institute, National Research University Higher School of Economics, Ph.D.

Research area: intercultural relations in plural societies, psychological adaptation to acculturation, ecological and cultural factors in human development, comparative methodology.

E-mail: jwberry@hse.ru

Victoria N. Galyapina - leading research fellow, International Scientific-Educational Laboratory for Socio-Cultural Research, Expert Institute; associate professor, Faculty of Social Sciences, School of Psychology, National Research University Higher School of Economics, Ph.D. Research area: cross-cultural psychology, intercultural relations, values and norms, identity.

E-mail: vgalyapina@hse.ru

Nadezhda M. Lebedeva - head, International Laboratory for Socio-Cultural Research, Expert Institute; professor, Department of Psychology, Faculty of Social Sciences, National Research University "Higher School of Economics", D.Sc., professor.

Research area: ethnic and cross-cultural psychology, intercultural relations, acculturation of migrants, values transmission, creativity, innovation.

E-mail: nlebedeva@hse.ru

Zarina Kh. Lepshokova - senior research fellow, International Scientific-Educational Laboratory for Socio-Cultural Research, Expert Institute; associate professor, Faculty of Social Sciences, School of Psychology, National Research University Higher School of Economics, Ph.D.

Research area: social and cross-cultural psychology, intercultural relations, acculturation, values, multiple identities.

E-mail: taimiris@yandex.ru; zlepshokova@hse.ru 
Tatiana A. Ryabichenko - senior research fellow, International Scientific-Educational Laboratory for Socio-Cultural Research, Expert Institute; associate professor, Faculty of Social Sciences, School of Psychology, National Research University Higher School of Economics, Ph.D. Research area: intercultural relations, acculturation, values, cultural continuity, identity.

E-mail: tryabichenko@hse.ru

\title{
Межкультурные отношения в Грузии и Таджикистане: постконфликтная модель
}

\author{
Д.У. Берри ${ }^{\mathrm{a}, \mathrm{b}}$, В.Н. Галяпина ${ }^{\mathrm{b}}$, Н.М. Лебедева ${ }^{\mathrm{b}}$, 3.Х. Лепшокова ${ }^{\mathrm{b}}$, Т.А. Рябиченко \\ ${ }^{a}$ Университет Куинс, 154 Albert Str., Kingston, ON, Canada, K7L 3N6

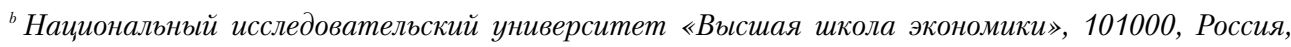 \\ Москва, ул. Мясницкая, д. 20
}

\section{Резюме}

В статье представлены результаты исследований межкультурных отношений в постсоветских Грузии и Таджикистане. Для обеих стран характерно резкое снижение культурного разнообразия в результате войн и конфликтов, в связи с чем модель межкультурного взаимодействия в данных странах определяется как постконфликтная (Lebedeva, 2018). Цель исследования состояла в проверке трех гипотез межкультурных отношений: мультикультурализма, контакта и интеграции (Berry, 2017) среди русского меньшинства и этнического большинства Грузии и Таджикистана. В Грузии в исследовании приняли участие 298 грузин и 312 русских, в Таджикистане 317 таджиков и 277 русских. Методологию исследования составили шкалы из опросника MIRIPS (Mutual Intercultural Relations in Plural Societies). Проверка гипотез исследования проводилась с помощью моделирования структурными уравнениями (SEM). Гипотеза мультикультурализма подтвердилась частично во всех выборках. Гипотеза контакта подтвердилась частично у таджиков и русских в Грузии и не подтвердилась у грузин и русских в Таджикистане. Гипотеза интеграции полностью подтвердилась у таджиков и русских в Грузии, частично подтвердилась у русских в Таджикистане и не подтвердилась у грузин. Полученные результаты исследований обсуждаются в статье с учетом социокультурного контекста и истории войн и конфликтов.

Ключевые слова: этническое меньшинство, этническое большинство, межкультурные отношения, мультикультурализм, контакт, интеграция, постсоветский период, Грузия, Таджикистан.

Берри Джон Уиддап - почетный профессор психологии, Университет Куинс (Кингстон, Канада); главный научный сотрудник, Международная научно-учебная лаборатория социокультурных исследований, Экспертный институт, Национальный исследовательский университет «Высшая школа экономики», Ph.D., профессор.

Сфера научных интересов: межкультурные отношения в поликультурных обществах, психологическая адаптация к аккультурации, экологические и культурные факторы развития человека, сравнительная методология.

Контакты: jwberry@hse.ru 
Галяпина Виктория Николаевна - ведущий научный сотрудник, Международная научноучебная лаборатория социокультурных исследований, Экспертный институт; доцент, департамент психологии, факультет социальных наук, Национальный исследовательский университет «Высшая школа экономики», кандидат психологических наук, доцент.

Сфера научных интересов: кросс-культурная психология, межкультурные отношения, ценности и нормы, идентичность.

Контакты: vgalyapina@hse.ru

Лебедева Надежда Михайловна - заведующая, Международная научно-учебная лаборатория социокультурных исследований, Экспертный институт; профессор, департамент психологии, факультет социальных наук, Национальный исследовательский университет «Высшая школа экономики», доктор психологических наук, профессор.

Сфера научных интересов: этническая и кросс-культурная психология, межкультурные отношения, аккультурация мигрантов, трансмиссия ценностей, креативность, инновации.

Контакты: nlebedeva@hse.ru

Лепшокова Зарина Хизировна - старший научный сотрудник, Международная научноучебная лаборатория социокультурных исследований, Экспертный институт; доцент, департамент психологии, факультет социальных наук, Национальный исследовательский университет «Высшая школа экономики», кандидат психологических наук.

Сфера научных интересов: социальная и кросс-культурная психология, межкультурные отношения, аккультурация, ценности, множественные идентичности.

Контакты: zlepshokova@hse.ru

Рябиченко Татьяна Анатольевна - старший научный сотрудник, Международная научноучебная лаборатория социокультурных исследований, Экспертный институт; доцент, департамент психологии, факультет социальных наук, Национальный исследовательский университет «Высшая школа экономики», кандидат психологических наук.

Сфера научных интересов: межкультурные отношения, аккультурация, ценности, культурная преемственность, идентичность.

Контакты: tryabichenko@hse.ru 